\title{
FASILITASI PERDAGANGAN, KINERJA EKSPOR, DAN KETIMPANGAN PENDAPATAN DI NEGARA-NEGARA RCEP
}

\author{
Ra'iyatu Imadidin', Dominicus Savio Priyarsono², Widyastutik ${ }^{2}$ \\ ${ }^{1}$ Mahasiswa Program Magister Ilmu Ekonomi, FEM IPB \\ ${ }^{2}$ Staff Pengajar FEM IPB
}

\begin{abstract}
The growth of global economic integration has added pressure for countries to reduce trade cost to make trades more profitable and to encourage their further development. As tariffs have progressively fallen, efforts in trimming trade costs have focused increasingly on non tariff measures, which have a detrimental impact on the free flow of international trade, as such trade facilitation is considered an important complement to trade liberalization efforts aimed at fostering economic integration. Trade is expected to increase overall national income. The increase in national income can be used to improve welfare by increasing household income which translates into inequality alleviation. Regional Comprehensive Economic Partnership (RCEP) is a form of cooperation between 16 countries in the Association of Southeast Asian Nation and other major trading partner countries. This study uses a simultaneous panel method to identify the trade facilitation, export performance, and income inequality by using 12 countries in the RCEP region during 2011-2015 period. The results show that the advantages of trade facilitation in RCEP associated with export performance to decrease inequality in RCEP region and RCEP developing countries, but increase increase in RCEP developed countries.
\end{abstract}

Keywords: Export performance, Inequality, RCEP, Trade facilitation

\section{PENDAHULUAN}

Globalisasi mengacu pada peningkatan integrasi antar negara atau masyarakat yang berbeda di dunia. Sejak pembentukan The General Agreement on Tariff and Trade (GATT) dan kemudian menjadi The world Trade Organization (WTO) maka negaranegara anggota yang tergabung dalam WTO dapat dengan mudah melakukan perdagangan sesuai dengan perjanjian yang telah disepakati secara bilateral, multilateral, dan unilateral.

Tingginya integrasinya perdagangan antar negara di dunia maka ekonomi nasional di sisi lain harus berusaha mengimbangi perubahan sistem ekonomi dengan menderegulasi hambatan perdagangan internasional mereka melalui perjanjian perdagangan. Integrasi ekonomi pada dasarnya merupakan implementasi dari liberalisasi perdagangan yang akan memberikan keuntungan bagi negaranegara yang terlibat di dalamnya dan meningkatkan kesejahteraannya. Hal terpenting dalam liberalisasi perdagangan telah dibahas dalam perjanjian WTO yaitu dengan mengurangi hambatan arus perdagangan untuk meningkatkan per-dagangan antar negara-negara anggota (Matsumura, 2016).

Hambatan-hambatan tersebut berupa hambatan tarif dan non-tarif. Dengan semakin menurunnya hambatan tarif secara progresif, upaya pemangkas- 
an biaya perdagangan semakin terfokus pada ukuran hambatan non tarif yang berdampak buruk pada arus barang yang diperdagangkan secara internasional. Sejak dimasukkan dalam agenda WTO tahun 1994 dan telah dimulai negosiasi untuk anggota WTO sejak tahun 2004, fasilitasi perdagangan dianggap sebagai pelengkap penting bagi adanya liberalisasi perdagangan yang bertujuan untuk mendorong integrasi ekonomi (Pellan dan Wong, 2015; Asian Development Bank dan United nation, 2013).

Fasilitasi perdagangan semakin diakui sebagai kunci untuk membuka keuntungan yang lebih dari perdagangan internasional. Secara umum, inti negosiasi WTO pada fasilitasi perdagangan mengacu pada sekumpulan kebijakan yang digunakan untuk mengurangi biaya dari proses ekspor dan impor (Wilson et al., 2005). Dalam literatur yang ada menunjukkan bahwa keuntungan dari fasilitasi perdagangan sangat besar. Portugal-Perez dan Wilson (2012), Shepherd dan Wilson (2009) menunjukkan bahwa reformasi fasilitasi perdagangan memperbaiki kinerja ekspor negara-negara yang melakukannya terutama berlaku untuk investasi secara fisik seperti reformasi infrastruktur transportasi, teknologi dan peraturan untuk memperbaiki lingkungan bisnis.

Pada kawasan Asia Selatan menunjukkan keuntungan ke wilayah tersebut diperkirakan mencapai \$31 miliar pada tahun 2007 dan \$ 26 miliar pada tahun 2010 jika Asia Selatan dan seluruh dunia meningkatkan tingkat fasilitasi perdagangan ke setengah ratarata dunia (Otsuki et al., 2012). Itakura (2014) menunjukkan bahwa dengan mengurangi hambatan perdagangan secara signifikan memberikan dampak positif terhadap kesejahteraan ekonomi, selain itu ditemukan bahwa Regional
Comprehensive Economic Partnership (RCEP) adalah FTA yang memberikan dampak positif terbesar terhadap GDP riil untuk sebagian besar ASEAN Member States (AMS). RCEP adalah bentuk kerjasama antara 16 Negaranegara di kawasan Asia anggotanya adalah Association of Southeast Asian Nation (ASEAN) dan negara-negara mitra dagang utama lainnya seperti Australia, Korea Selatan, Jepang, China, New Zealand dan India.

Lebih dari $50 \%$ populasi di dunia berada dalam negosiasi tersebut, yang mencakup lebih dari seperempat dari keseluruhan ekspor global dan hampir $30 \%$ dari PDB dunia. Seperti perjanjian perdagangan yang lain, negosiasi ini termasuk fokus pada perdagangan liberalisasi, menangani berbagai peraturan perjanjian. Dengan dipercepatnya pengembangan yang disebut mega Regional Trade Agreement (RTA), keduanya yaitu ekonomi negara maju dan ekonomi negara berkembang sedang membangun dan berinvestasi pada jaringan perdagangan regional. Kelompok RCEP ini terdiri dari anggota 16 negara Asia dan Pasifik yang beragam menyusun kesepakatan untuk memperdalam integrasi perdagangan dan melakukan perdagangan yang lebih komprehensif.

Berdasarkan kajian empiris terdahulu, fasilitasi perdagangan dapat meningkatkan perdagangan internasional suatu negara, maka dapat meningkatkan pertumbuhan ekonomi dan mempengaruhi distribusi pendapatan negara terutama untuk negaranegara sedang berkembang (Pellan dan Wong, 2015). Pertumbuhan ekonomi merupakan prasyarat untuk mengurangi ketimpangan (Dollar dan Kraay, 2000; Ravallion, 2004).

Perdagangan internasional dapat mempengaruhi upah riil, sehingga akan berdampak pada pendapatan, menurut 
teorema Stolpher-Samuelson, jika harga produk dengan labour intensive meningkat maka produksi dan lapangan kerja akan meningkat, dan akan menyebabkan kenaikan upah riil dan sebaliknya, penurunan harga akan menyebabkan penurunan upah (Cuong, 2013). Ketika sebuah perekonomian membuka diri secara global khususnya dalam perdagangan dunia, maka hal ini memungkinkan untuk mendapatkan keuntungan dari adanya globalisasi. Perdagangan diharapkan dapat meningkatkan pendapatan nasional secara keseluruhan. Kenaikan pendapatan nasional kemudian dapat digunakan untuk perbaikan kesejahteraan masyarakat melalui peningkatan pendapatan rumah tangga (Cabote, 2014). Namun, efek fasilitasi perdagangan terhadap ketimpangan tidak selalu dapat diketahui secara apriori. Selain itu beberapa kajian studi terdahulu meyatakan bahwa liberalisasi perdagangan menyebabkan dampak yang negatif terhadap upah (Revenga, 1997; Marquez dan Pages, 1998). Pengaruh dorongan perdagangan internasional terhadap ketimpangan tidak dapat diprediksi dengan pasti, karena perdagangan internasional dapat mempunyai efek heterogen pada obyek yang berbeda (Cuong, 2013).

Adanya teori dan hasil empiris yang masih menjadi perdebatan mengenai pengaruh fasilitasi perdagangan terhadap ketimpangan membuat kajian akan pengaruh fasilitasi perdagangan dan kinerja ekspor terhadap ketimpangan di kawasan RCEP penting untuk diteliti. Hal ini dikarenakan kawasan RCEP memiliki lebih dari $50 \%$ populasi di dunia berada dalam negosiasi tersebut, yang mencakup lebih dari seperempat dari keseluruhan ekspor global dan hampir $30 \%$ dari PDB dunia. Selain itu kawasan RCEP dengan anggota negara- negara yang maju dan berkembang yang memiliki pengaruh yang berbeda dengan adanya fasilitasi perdagangan. Sehingga penelitian ini pada akhirnya dapat memberikan sebuah kesimpulan penting apakah adanya fasilitasi perdagangan mengurangi kemiskinan di kawasan RCEP atau justru sebaliknya. Oleh karena itu penelitian ini bertujuan untuk; (1) Memberikan gambaran dari fasilitasi perdagangan dan kinerja ekspor di kawasan RCEP (2) Menganalisis pengaruh fasilitasi perdagangan terhadap kinerja ekspor di kawasan RCEP (3) Menganalisis pengaruh kinerja ekspor terhadap ketimpangan di kawasan RCEP.

\section{TINJAUAN PUSTAKA}

\section{Kemiskinan dan Ketimpangan}

Kemiskinan didefinisikan sebagai hidup di bawah persyaratan minimum untuk makan, kondisi kehidupan atau variabel kesejahteraan penting lainnya. Untuk pengukuran kemiskinan, perlu untuk mengidentifikasi variabel kesejahteraan moneter dan non-moneter yang memungkinkan penilaian kesejahteraan individu, dan untuk memilih ukuran ambang batas individu yang dianggap sebagai orang miskin. Beberapa ambang batas dapat membantu membedakan berbagai tingkat kemiskinan.

Pandangan yang paling konvensional, dan titik awal untuk sebagian besar analisis kemiskinan, adalah mengukurnya dalam istilah moneter. Seseorang dianggap miskin jika yang dikonsumsi atau pendapatannya turun di bawah tingkat minimum (garis kemiskinan) yang diperlukan untuk memenuhi kebutuhan dasar. Apa yang diperlukan untuk memenuhi kebutuhan dasar, bervariasi sepanjang waktu. 
Oleh karena itu, ketika memperkirakan kemiskinan di tingkat negara, garis kemiskinan bervariasi setiap waktu dan tempat, dan juga sesuai dengan tingkat pembangunan negara, norma dan nilai masyarakat. Saat memperkirakan kemiskinan di seluruh dunia, dibutuhkan garis referensi yang serupa yang dinyatakan sebagai Common Unit Across Countries. Untuk tujuan agregasi global dan perbandingan, garis referensi yang biasanya digunakan ditetapkan pada $\$$ 1,25 dan $\$ 2$ per hari, masing-masing atau disebut dengan istilah Purchasing Power Parity.

Ringkasan indeks tingkat kemiskinan, berdasarkan ukuran moneter, adalah:

1. Indeks jumlah kepala (yang mengukur proporsi populasi berada di bawah garis kemiskinan).

2. Indeks kesenjangan kemiskinan (yang mengukur sejauh mana individu berada di bawah garis kemiskinan).

3. Indeks tingkat kemiskinan (dengan menambahkan kesenjangan kemiskinan untuk mengukur ketidaksetaraan di antara orang miskin).

4. Indeks Sen-Shorrocks-Thon (yang menggabungkan ukuran proporsi kemiskinan, tingkat kemiskinan, dan distribusi kesejahteraan di antara orang miskin).

Kemiskinan dikaitkan tidak hanya dengan pendapatan atau konsumsi yang tidak mencukupi, tapi juga dengan tingkat kesejahteraan yang tidak mencukupi misalnya, berkaitan dengan kesehatan, gizi dan keaksaraan, hubungan sosial, keamanan dan kepercayaan diri. Untuk mengukur kemiskinan terhadap indikator nonmoneter, maka layak untuk membandingkan nilai ambang batas atau garis kemiskinan.
Fenomena kemiskinan adalah masalah multidimensi. Dengan pendekatan tradisional untuk mengumpulkan berbagai indikator dari berbagai dimensi kemiskinan dan menganalisisnya bersama-sama, oleh karena itu, kemiskinan sering dikaitkan dengan ketimpangan, namun ketimpangan berfokus pada distribusi atribut, seperti pendapatan atau konsumsi, secara keseluruhan dalam populasi.

\section{Fasilitasi Perdagangan dan Ketimpangan Pendapatan}

Pengurangan biaya transaksi ekspor dan impor yang terkait dengan fasilitasi perdagangan ditransmisikan ke masyarakat miskin terutama melalui jalur perdagangan internasional dan domestik, yang beroperasi baik pada sisi produksi maupun di sisi konsumsi. Di sisi produksi, daya saing barang ekspor cenderung meningkat kemudian dalam jangka pendek karena input impor lebih murah dan akan mengurangi biaya ekspor. Oleh karena itu, upah dan / atau lapangan kerja di sektor ini cenderung meningkat. UKM adalah sektor yang kemungkinan akan mendapatkan keuntungan paling banyak dari tindakan ini karena UKM umumnya menanggung tidak proporsionalnya biaya transaksi per-dagangan, terutama di negara berkembang. Seperti prosedur perdagangan yang efisien, UKM dapat didorong untuk lebih terlibat langsung dalam impor dan ekspor.

Di sisi konsumsi, pengurangan biaya transaksi pada saluran perdagangan internasional juga mempengaruhi masyarakat miskin melalui perubahan harga dan aneka barang yang dikonsumsi. Saat pasar sedang berfungsi secara efisien, harga barang impor dalam negeri menurun, selanjutnya harga barang substitusi domestik bisa jatuh karena 
berkurangnya kesempatan untuk mendapatkan sewa oleh produsen dalam negeri, namun, harga barang dalam negeri juga bisa meningkat pada beberapa kesempatan, misalnya jika barang-barang ini juga bisa diekspor dan harganya di pasar dunia lebih tinggi dari harga domestik. Akibatnya, aliran ekspor dapat menciptakan harga yang lebih tinggi dan akan mengurangi pasokan di pasar domestik dan pada akhirnya akan menyebabkan kenaikan harga domestik.

Terakhir, barang yang sebelumnya tidak dapat diperoleh dapat tersedia, terkait dengan keuntungan kesejahteraan. Pada akhirnya, sejauh mana masyarakat bisa mendapatkan keuntungan bergantung pada tingkat persaingan dan diferensiasi produk dalam pasar seperti jenis barang yang perdagangan yang difasilitasi.

Saluran perdagangan internasional juga dapat mempengaruhi perdagangan dalam negeri dan pada gilirannya pada pendapatan masyarakat. Meningkatnya persaingan yang dihadapi produsen dalam negeri di sektor-sektor yang bersaing dengan impor dan harga input impor menurun, proses spesialisasi yang sama dan realokasi sumber daya terhadap kegiatan yang mencerminkan keunggulan komparatif negara dan eksploitasi skala ekonomi kemungkinan besar terjadi dalam perdagangan dalam negeri. Selain itu, sebagian besar eksportir cenderung memasok sebagian produksinya ke pasar dalam negeri, dan langkah-langkah fasilitasi perdagangan dapat berkontribusi untuk meningkatkan kualitasnya daya saing di pasar domestik.

Langkah-langkah fasilitasi perdagangan juga bisa menguntungkan produsen dalam negeri karena pengurangan biaya dan waktu untuk mencapai pasar domestik. Hal ini, pada gilirannya, dapat menguntungkan konsumen. Langkah-langkah fasilitasi perdagangan yang melibatkan peningkatan TIK juga dapat membantu produsen untuk menghemat waktu dan uang karena komunikasi yang lebih efisien, pasokan informasi strategis mengenai harga pasar, dan memungkinkan perencanaan dan pengangkutan barang ke pasar lokal.

Dalam jangka pendek, proses penyesuaian bisa berarti turunnya upah atau pekerjaan di sektor tertentu. Namun, dalam jangka menengah sampai jangka panjang lebih efisiennya lingkungan perdagangan cenderung meningkatkan kesejahteraan negara. Perusahaan akan didorong untuk mengambil spesialisasi dalam meng-ekspor barang-barang yang mencermin-kan keunggulan komparatif negara tersebut seperti mengeksploitasi skala ekonomi.

Menurut model Heckscher Ohlin, upah atau lapangan kerja akan turun dalam produksi barang yang ekspornya di berkurang, sementara itu perusahaan akan meningkatkan barang yang ekspornya meningkat. Efeknya terhadap masyarakat bergantung pada mobilitas di pasar tenaga kerja dan karakteristik dari rantai distribusi, dan juga pada kemauan politik pemerintah untuk memberikan safety-nets sepanjang proses penyesuaian ini terjadi. Akhirnya, melalui jalur perdagangan internasional, volatilitas harga cenderung meningkat karena akan ada lebih banyak eksposur terhadap fluktuasi harga internasional.

\section{METODE PENELITIAN}

\section{Jenis dan Sumber Data}

Jenis data yang digunakan pada penelitian ini adalah data sekunder berupa data panel yaitu gabungan data deret lintang (cross section) dan data deret waktu (time series). Data cross 
section digunakan untuk 12 negara anggota RCEP dikarenakan keterbatasan data, sedangkan data time series dari tahun 2011 sampai dengan 2015. Data sekunder diperoleh dari UN Comtrade, CEPII, WITS, World Bank, dan publikasi internasional seperti Global Competitiveness Report dan Doing Business.

\section{Metode Analisis dan Pengolahan Data}

Metode yang digunakan dalam penelitian ini ada dua, analisis deskriptif digunakan untuk menggambarkan implementasi fasilitasi perdagangan dan kinerja ekspor terhadap kemiskinan dari negara anggota RCEP. Sedangkan metode kuantitatif digunakan untuk mengukur dampak fasilitasi perdagangan terhadap kinerja ekspor dan kemiskinan dari negara anggota RCEP dengan metode analisis simultan Two Stage Least Square (2SLS) dan digunakan model gravitasi panel serta beberapa variabel fasilitasi perdagangan, kemiskinan, ekspor dan variabel lainnya yang berhubungan dengan ekspor. Adapun pengolahan data yang dilakukan menggunakan software microsoft excel 2010 dan Eviews 9.

\section{Analisis Parsial Simultan Panel}

Pada penelitian ini analisis regresi yang digunakan adalah analisis regresi data panel statis. Analisis data panel statis merupakan analisis data panel yang regressor-nya tidak melibatkan variabel lag dependent dalam model. Adapun regresi yang digunakan dalam panel statis ini adalah regresi parsial simultan panel. Alasan pemilihan metode parsial simultan mengacu pada tujuan penelitian yang ingin melihat pengaruh fasilitasi perdagangan terhadap kemiskinan secara parsial. Ada transmisi mekanisme dalam melihat pengaruh fasilitasi perdagangan terhadap kemiskinan. Fasilitasi perdagangan tidak berpengaruh secara langsung terhadap pengentasan kemiskinan, tetapi fasilitasi per-dagang-an berpengaruh terhadap kinerja ekspor, dan kinerja ekspor tersebut yang berpengaruh terhadap kemiskinan.

Suatu sistem persamaan simultan (simultaneous-equations system) ialah suatu himpunan persamaan dimana variabel tak bebas dalam satu atau lebih persamaan juga merupakan variabel bebas dalam beberapa persamaan lainnya, yaitu keadaan di mana di dalam sistem persamaan suatu variabel sekaligus mempunyai dua peranan, yaitu sebagai variabel tak bebas dan variabel bebas. Oleh karena itu, pemberian nama variabel bebas dan variabel tak bebas di dalam sistem persamaan simultan sudah tidak tepat lagi. Sehingga untuk selanjutnya dalam persamaan simultan akan ada yang namanya variabel endogen dan variabel yang ditetapkan lebih dulu (predetermined variable).

Variabel yang ditetapkan lebih dulu bisa berupa variabel eksogen sekarang, eksogen waktu lampau dan endogen waktu lampau. Variabel endogen ialah variabel tak bebas di dalam sistem persamaan simultan, yang nilainya ditentukan di dalam sistem persamaan, walaupun variabel-variabel tersebut mungkin juga muncul sebagai variabel bebas di dalam sistem persamaan. Variabel eksogen ialah variabel yang nilainya ditentukan di luar model. Dalam persamaan simultan perlu dilakukan identifikasi model terlebih dahulu sebelum memilih metode untuk menduga parameter pada setiap persamaan. Suatu persamaan dikatakan teridentifikasi kalau koefisiennya dapat diperkirakan.

Model persamaan simultan dengan kondisi setiap persamaannya teridentifikasi berlebih, maka penduga- 
an parameter dapat meng-gunakan beberapa metode yang ada seperti two stage least square (2 SLS) atau three stage least square (3 SLS). Namun, penelitian ini menggunakan metode 2 SLS. Analisis parsial simultan dapat diestimasi dengan menggunakan teknik least square estimator. Pada tahap pertama, persamaan pertama diestimasi dengan menggunakan OLS. Tahap selanjutnya adalah mengestimasi persamaan kedua dengan menggunakan OLS juga, namun dengan mengganti nilai variabel endogen dengan nilai prediksi dari hasil regresi sebelumnya.

\section{Model Gravitasi}

Model gravitasi muncul sebagai salah satu model empiris di bidang perdagangan internasional untuk mempelajari efek ex-post perjanjian perdagangan bebas dan serikat kepabeanan dalam aliran perdagangan bilateral. Konsep klasik dari model gravitasi secara original dikenalkan oleh yang terinspirasi oleh Hukum Newton. Hukum ini menyatakan bahwa setiap titik massa menarik setiap massa titik lainnya dengan gaya gravitasi. Dalam konteks perdagangan, model ini menyatakan bahwa intensitas atau volume perdagangan antara kedua negara akan berhubungan secara proporsional dengan "massa" ekonomi (pendapatan nasional) masing-masing negara, dan berhubungan terbalik secara proporsional dengan jarak diantara keduanya.

$\mathbf{F i j}=G^{*}+(\mathbf{M i} * \mathbf{M j}) / \mathbf{D i j}$

dimana $F$ merupakan volume perdagangan bilateral, $M$ merupakan besarnya ekonomi masing-masing negara, D merupakan jarak bilateral kedua negara, dan $\mathrm{G}$ adalah konstanta.

\section{Spesifikasi Model}

Spesifikasi model yang digunakan dalam penelitian ini mengacu pada model data panel dari Shepherd (2009), Portugal-Perez (2012), Otsuki et al. (2013), Cuong (2013) dan Cabote (2014) dengan beberapa modifikasi yang dilakukan mengikuti ketersediaan data.

Model Ekspor:

$$
\begin{aligned}
& \ln X_{i t}=\beta_{0}+\beta_{1} \ln G D P C_{i t}+\beta_{2} \ln \text { SDPC }_{j t}+ \\
& \beta_{3} \ln P H Y S_{i t}+\beta_{4} \ln P H Y S_{j t}+\beta_{5} \ln B U S S_{i t}+ \\
& \beta_{6} \\
& \operatorname{lnBUSS}_{\mathbf{j t}}+\beta_{7} \ln C U S T_{\mathbf{i t}}+\beta_{8} \ln C U S T_{\mathbf{j t}}+\beta_{9} \\
& \operatorname{lnICT} T_{i t}+\beta_{10} \ln I C T_{j t}+\beta_{11} \ln E X C_{i j t}+\beta_{12} \ln \\
& \text { TAR }_{\mathbf{j t}}+\beta_{13} \ln \text { IST }_{\mathrm{ij}}+\beta_{14} \text { CONTIG }_{\mathrm{ij}}+\beta_{15} \\
& \operatorname{COMCOL}_{\mathrm{ij}}+\beta_{16} \mathrm{COMLANG}_{\mathrm{ij}}+\varepsilon_{\mathrm{ij}} \\
& \text { Model Ketimpangan: } \\
& \operatorname{lnGINI}{ }_{i t}=\alpha_{0}+\alpha_{1} \ln X_{i t}+\alpha_{2} X R C E P D E V E \\
& \text { LOPED }_{i t+\alpha_{3} X D E V E L O P E D}{ }_{i t}+\text { vij }
\end{aligned}
$$

Dimana $\mathrm{X}_{\mathrm{ijt}}$ adalah Ekspor negara i ke negara $\mathrm{j}$ pada tahun $\mathrm{t}, \mathrm{GDPC}_{\mathrm{it}}$ dan $\mathrm{GDPC}_{\mathrm{jt}}$ adalah Gross domestic product negara $\mathrm{i}$ dan $\mathrm{j}$ pada tahun $\mathrm{t}, \mathrm{PHYS}_{\mathrm{it}}$ dan PHYS $_{j t}$ adalah Infrastruktur negara $\mathrm{i}$ pada tahun t, BUSS $S_{\text {it }}$ dan BUSS $_{\mathrm{jt}}$ adalah Lingkungan bisnis negara $\mathrm{i}$ dan $\mathrm{j}$ pada tahun t, CUST it dan CUST $_{\mathrm{jt}}$ adalah Prosedur bea cukai negara $i$ dan $j$ pada tahun $\mathrm{t}, \mathrm{ICT}_{\mathrm{it}}$ dan $\mathrm{ICT}_{\mathrm{jt}}$ adalah Teknologi informasi dan komunikasi negara $\mathrm{i}$ pada tahun $\mathrm{t}, \mathrm{EXC}_{\mathrm{ijt}}$ adalah Nilai tukar negara $i$ terhadap negara $j$ pada tahun $t$, TAR $_{\mathrm{ijt}}$ adalah Tarif impor negara $\mathrm{i}$ dari negara $\mathrm{j}$ pada tahun $\mathrm{t}$, DIST $_{\mathrm{ijt}}$ adalah Jarak geografis antara negara i dengan negara $\mathrm{j}$, GINI $\mathrm{I}_{\mathrm{it}}$ adalah Rasio ketimpangan pendapatan negara i, RCEPDEVELOPED $_{\text {it }}$ adalah Variabel dummy sama dengan 1 untuk negara maju, sama dengan 0 untuk negara sedang berkembang, XDEVELOPEDit adalah Variabel slope dummy interaksi ekspor, CONTIGij adalah Variabel dummy sama dengan 1 jika negara i dan negara $\mathrm{j}$ berbagi tanah perbatasan, lainnya sama dengan 0, COMCOLij adalah Variabel dummy sama dengan 1 
jika negara $\mathrm{i}$ dan negara $\mathrm{j}$ dijajah oleh kekuatan yang sama, lainnya sama dengan 0, COMLANGij adalah Variabel dummy sama dengan 1 jika negara $\mathrm{i}$ dan negara $\mathrm{j}$ memiliki bahasa resmi yang sama, lainnya sama dengan 0 .

\section{HASIL DAN PEMBAHASAN}

\section{Fasilitasi Perdagangan, Kinerja, Ekspor dan Ketimpangan}

Gambar 1 menjelaskan mengenai biaya dan waktu yang digunakan ntuk mengekspor di kawasan RCEP. Dengan membagi menjadi 3 kelompok yaitu kawasan RCEP secara keseluruhan, negara maju di kawasan RCEP, negara sedang berkembang di kawasan RCEP dan dibandingkan dengan kawasan Asia Pasifik agar dapat dilihat perbedaannya. Pengukuran waktu dan biaya (tidak termasuk tarif) yang terkait dengan tiga perangkat prosedur yaitu kepatuhan dokumenter, kepatuhan perbatasan dan transportasi dalam negeri dalam keseluruhan proses pengekspor atau pengangkutan barang dimana semua formalitas tersebut merupakan implementasi dari fasilitasi perdagangan.

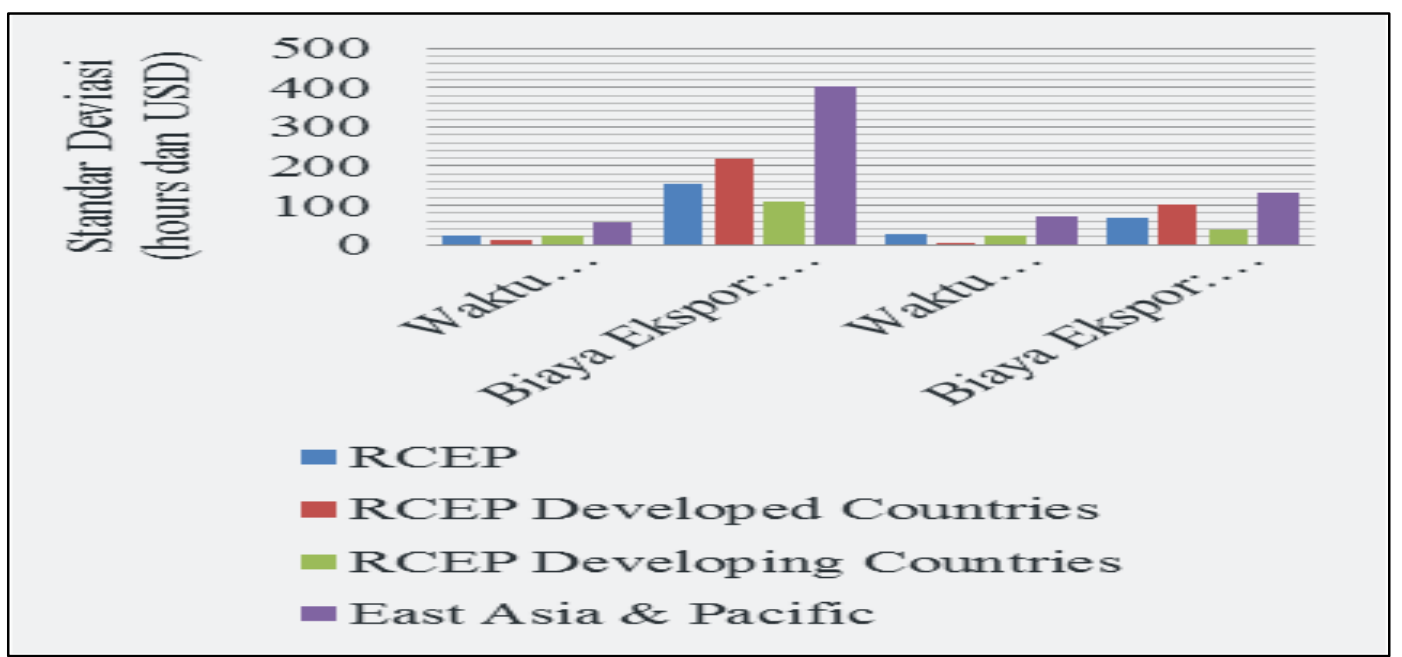

Sumber: Doing Business, 2017 (diolah)

Gambar 1 Rata-Rata Biaya dan Waktu yang Digunakan untuk Mengekspor di Kawasan RCEP tahun 2011-2015

Gambar tersebut memperlihatkan bahwa jika dibandingkan dengan kawasan Asia Pasifik, negara-negara maju di kawasan RCEP dan negaranegara sedang berkembang di kawasan RCEP, biaya dan waktu yang digunakan untuk mengekspor di kawasan RCEP lebih rendah, artinya bahwa kawasan RCEP memiliki potensi yang baik untuk dapat mengembangkan ekspor di kawasan tersebut mengingat memegang hampir dari $25 \%$ ekspor global. 


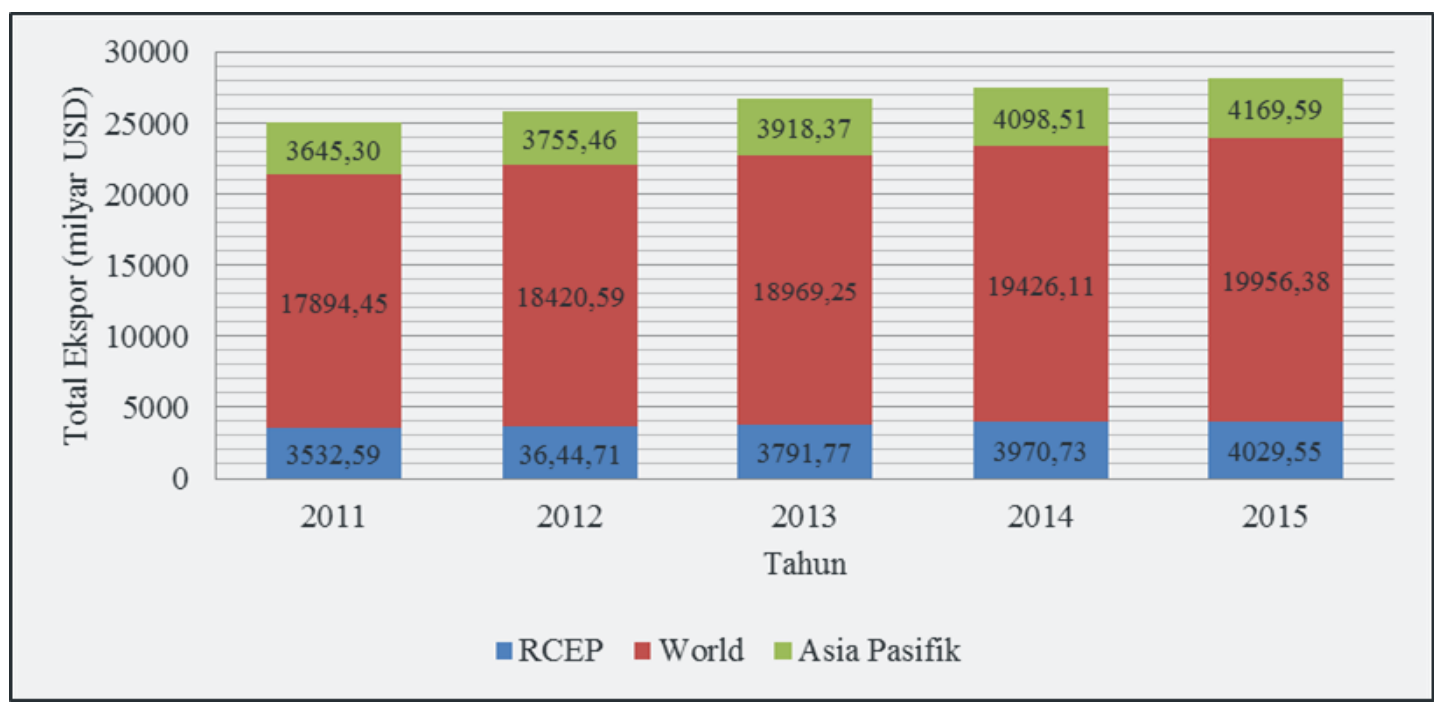

Sumber: World Bank, 2017 (diolah)

Gambar 2 Perkembangan Nilai Total Ekspor di Kawasan RCEP Tahun 2011-2015 (milyar US\$)

Gambar 2 menjelaskan pergerakan nilai total ekspor di kawasan RCEP yang menunjukkan peningkatan dari tahun 2011-2015. Selain itu dari grafik tersebut dapat memperlihatkan bahwa nilai ekspor di kawasan RCEP cukup besar dari total nilai ekspor global serta jika dibandingkan dengan kawasan Asia Pasifik yang memiliki sebanyak 36 negara anggota sedangkan RCEP sebanyak 16 negara anggota. Hal ini menunjukkan bahwa kawasan RCEP memegang peranan penting dalam ekspor dunia, sehingga diharapkan dapat meningkatkan pertumbuhan ekonomi negara anggotanya yang kemudian dapat mengurangi ketimpangan.

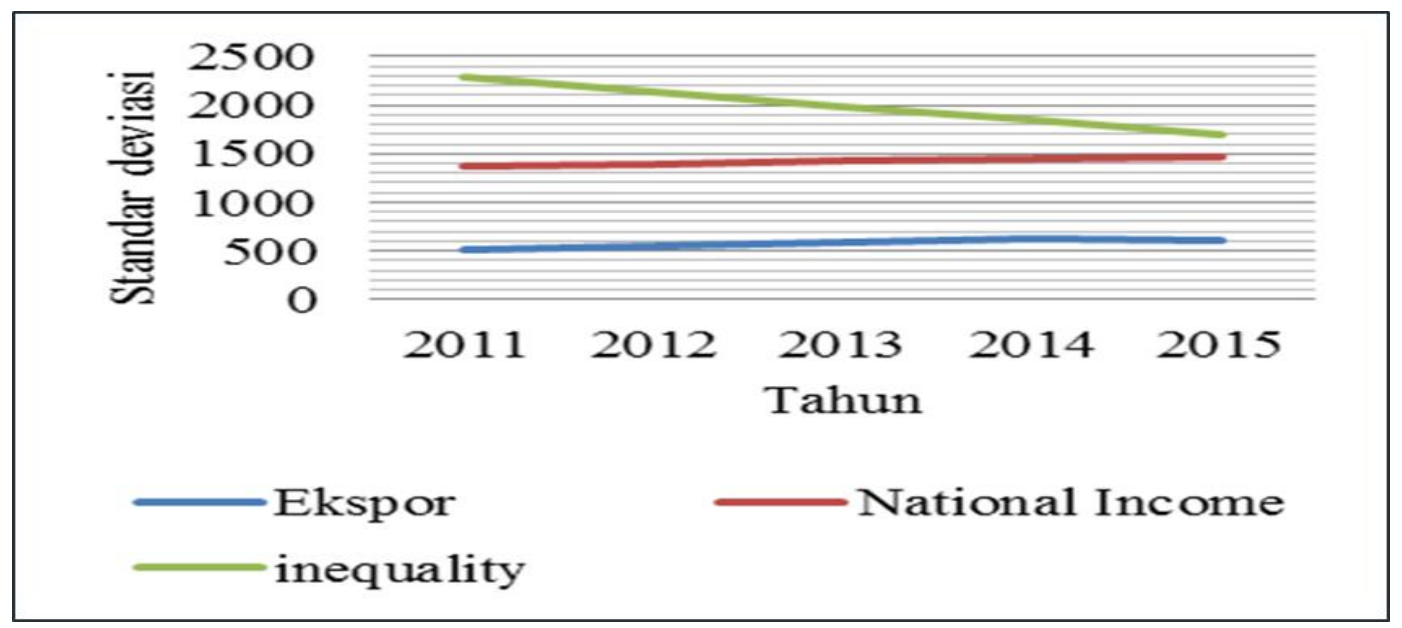

Sumber: World Bank (2017) dan UN Comtrade (2017)

Gambar 3 Grafik Pergerakan Data Nilai Ekspor, pendapatan Nasional dan Kemiskinan di Kawasan RCEP Tahun 2011-2015.

Gambar 3 menjelaskan pergerakan nilai ekspor, pendapatan nasional, dan ketimpangan pendapatan di kawasan
RCEP pada tahun 2011-2015. Pada gambar diperlihatkan hubungan yang positif antara ekspor dan pendapatan 
nasional dan hubungan negatif dengan kemiskinan. Hal ini menunjukkan bahwa kenaikan ekspor dikawasan RCEP secara grafik dapat menurunkan ketimpangan melalui kenaikan pendapatan nasional.

\section{Fasilitasi Perdagangan dan Kinerja Ekspor Terhadap Ketimpangan di Kawasan RCEP}

Penggunaan metode data panel, pabila terdapat variabel yang fixed atau konstan over time seperti jarak, lokasi, variabel dummy maka model yang cocok digunakan adalah Random Effect Model (REM). REM mungkin digunakan karena asumsi bahwa unobserved effect tidak berkorelasi dengan semua explanatory variables, apakah explanatory variables fixed over time atau tidak.

Tabel 1 menyajikan hasil estimasi dari fasilitasi perdagangan dan kinerja ekspor terhadap ketimpangan di kawasan RCEP dengan menggunakan metode 2SLS. Dalam penelitian model yang digunakan terdapat dua model yang pertama untuk melihat pengaruh fasilitasi perdagangan serta beberapa variabel lain yang berpengaruh terhadap ekspor, yang kedua untuk melihat pengaruh variabel ekspor terhadap ketimpangan. Selain itu penelitian juga memasukkan variabel dummy interaksi RCEP developed countries $\times$ export. Hal ini dimaksudkan untuk melihat adanya kemungkinan pengaruh export yang berbeda antar kelompok negara terhadap ketimpangan seperti temuan dari Pellan dan Wong (2015).

Hasil estimasi model pertama menunjukkan bahwa infrastruktur fisik pada negara pengekspor memiliki pengaruh positif signifikan. Artinya, infrastruktur fisik bagi negara pengekspor akan memberikan efek positif bagi ekspor negara tersebut seperti temuan Portugal-Perez dan Wilson (2012), Otsuki et al.(2012). Namun sebaliknya infra truktur fisik negara pengimpor tidak berpengaruh signifikan terhadap ekspor negara pengekspor artinya bahwa pada infrastruktur fisik dapat meningkatkan ekspor kawasan RCEP tetapi tidak dengan berpengaruh signifikan terhadap impor kawasan RCEP. 
Tabel 1 Hasil Estimasi Fasilitasi Perdagangan dan Kinerja Ekspor Terhadap Ketimpangan di Kawasan RCEP

\begin{tabular}{|c|c|c|c|}
\hline \multicolumn{2}{|l|}{ Dependent Variable } & $\begin{array}{l}\text { Model 1: } \\
\text { Ekspor }\end{array}$ & $\begin{array}{l}\text { Model 2: } \\
\text { Ketimpangan }\end{array}$ \\
\hline \multicolumn{2}{|l|}{ GDP Perkapita Pengekspor } & $\begin{array}{r}0,843665^{* * *} \\
(0,0000)\end{array}$ & \\
\hline \multicolumn{2}{|l|}{ GDP Perkapita Pengimpor } & $\begin{array}{r}0,043144^{*} \\
(0,1070)\end{array}$ & \\
\hline \multicolumn{2}{|l|}{ Infrastruktur Fisik Pengekspor } & $\begin{array}{r}0,912352 * * * \\
(0,0000)\end{array}$ & \\
\hline \multicolumn{2}{|l|}{ Infrastruktur Fisik Pengimpor } & $\begin{array}{r}-0,399630 \\
(0,3639)\end{array}$ & \\
\hline \multicolumn{2}{|l|}{ Lingkungan Bisnis Pengekspor } & $\begin{array}{r}-2,043129 * * * \\
(0,0000)\end{array}$ & \\
\hline \multicolumn{2}{|l|}{ Lingkungan Bisnis Pengimpor } & $\begin{array}{r}0,393555^{* *} \\
(0,0243)\end{array}$ & \\
\hline \multicolumn{2}{|l|}{ Prosedur Bea Cukai Pengekspor } & $\begin{array}{r}-0,529329 * * * \\
(0,0006)\end{array}$ & \\
\hline \multicolumn{2}{|l|}{ Prosedur Bea Cukai Pengimpor } & $\begin{array}{r}-0,108886 \\
(0,3803)\end{array}$ & \\
\hline $\begin{array}{l}\text { Teknologi Informasi } \\
\text { Pengekspor }\end{array}$ & Komunikasi & $\begin{array}{r}-0,322832 * * * \\
(0,0000)\end{array}$ & \\
\hline \multicolumn{2}{|l|}{ Nilai Tukar } & $\begin{array}{r}-0,152434 * * * \\
(0,0001) \\
-4,22 \mathrm{E}-05 * * * \\
(0,0000)\end{array}$ & \\
\hline \multicolumn{2}{|l|}{ Tarif } & $\begin{array}{r}-0,000181 \\
(0,6289)\end{array}$ & \\
\hline \multicolumn{2}{|l|}{ Jarak Geografi } & $\begin{array}{r}-5,74 \mathrm{E}-05^{* * * *} \\
(0,0000)\end{array}$ & \\
\hline \multicolumn{2}{|l|}{ Perbatasan } & $\begin{array}{r}0,286437 * * * \\
(0,0001)\end{array}$ & \\
\hline \multicolumn{2}{|l|}{ Sejarah } & $\begin{array}{r}0,543105^{* *} \\
(0,0405)\end{array}$ & \\
\hline \multicolumn{2}{|l|}{ Bahasa } & $\begin{array}{r}-0,360917 * * * \\
(0,0000)\end{array}$ & \\
\hline \multicolumn{3}{|l|}{ Ekspor } & $\begin{array}{l}-0,010304 * * * \\
(0,0000)\end{array}$ \\
\hline \multicolumn{3}{|c|}{ Kelompok Negara Maju RCEP (dummy) } & $\begin{array}{l}-0,026005 * * * \\
(0,0000)\end{array}$ \\
\hline \multicolumn{3}{|l|}{ Ekspor Negara Maju } & $\begin{array}{l}-0,0000119 * \\
(0,0744)\end{array}$ \\
\hline
\end{tabular}

Keterangan: nilai dalam () merupakan $p$-value $* * *, * *, *$ signifikan pada $1 \%, 5 \%, 10 \%$ 
Sementara itu lingkungan bisnis negara pengekspor maupun negara pengimpor menunjukkan hasil estimasi yang berpengaruh signifikan. Pada negara pengekspor menunjukkan pengaruh yang negatif signifikan sedangkan pada negara pengimpor menunjukkan pengaruh positif signifikan, hal ini serupa dengan temuan Portugal-Perez dan Wilson (2012). Artinya, bahwa perbaikan lingkungan bisnis akan menurunkan nilai ekspor kawasan RCEP jika tidak diimbangi dengan kesiapan sumber daya dalam memenuhi kebutuhan ekspor dan mengakibatkan peningkatan impor di kawasan RCEP, selain itu dengan adanya peraturan di kawasan RCEP dimana negara peserta tidak boleh memberikan perlakuan yang berbeda antara perusahaan lokal dan TNCs akan semakin menurunkan ekspor.

Selanjutnya prosedur bea cukai negara pengekspor menunjukkan pengaruh negatif signifikan terhadap ekspor, artinya bahwa jika semakin meningkat hambatan prosedur bea cukai akan menurunkan nilai ekspor kawasan RCEP, namun prosedur bea cukai pada negara pengimpor menunjukkan pengaruh negatif tidak signifikan seperti temuan Otsuki et al. (2012) pada 101 negara di dunia. Kemudian teknologi informasi dan komunikasi menunjukkan pengaruh negatif signifikan di kedua negara pengekspor maupun pengimpor, artinya bahwa adanya peningkatan teknologi informasi dan komunikasi suatu negara akan menurunkan nilai ekspor kawasan ekspor. Hal ini sejalan dengan temuan Portugal-Perez dan Wilson (2012) yang melakukan penelitian di 101 negara di dunia menyatakan bahwa semakin kaya negara, semakin besar dampak marjinal teknologi informasi dan komunikasi terhadap kinerja ekspor dan sebaliknya, hal ini mengingat bahwa dalam penelitian ini dari 12 negara yang dijadikan sampel penelitian 5 diantaranya adalah negara maju dan 7 diantaranya adalah negara sedang berkembang.

Faktor-faktor lain juga dimasukan dalam estimasi ini, yaitu: GDP percapita, jarak geografis, dan beberapa variabel dummy seperti kesamaan bahasa, kedekatan geografis, dan kesamaan sejarah yang semuanya menggambarkan variabel gravitasi serta nilai tukar serta tarif adalah faktor lain yang mempengaruhi kinerja ekspor. Hasil estimasi GDP perkapita menunjukkan pengaruh positif signifikan di kedua negara pengekspor maupun pengimpor, artinya bahwa adanya peningkatan GDP perkapita akan meningkatkan nilai ekspor kawasan RCEP, hal ini sejalan dengan temuan Portugal-Perez dan Wilson (2012) dan Otsuki et al (2013) pada 101 negara di dunia, Shepherd dan Wilson (2009) di ASEAN, Cabote (2014) pada negara-negara sedang berkembang dan Cuong (2013) pada negara-negara dengan pendapatan rendah dan menengah.

Selanjutnya jarak ekonomi, variabel dummy kedekatan perbatasan geografis, dan kesamaan sejarah menunjukkan hasil yang positif signifikan terhadap nilai ekspor, sedangkan kesamaan bahasa menunjukkan hasil yang negatif signifikan, hal ini sejalan dengan temuan PortugalPerez dan Wilson (2012), Otsuki et al (2013), Shepherd (2009). Kemudian nilai tukar menunjukkan pengaruh negatif signifikan terhadap nilai ekspor, artinya bahwa adanya penguatan nilai tukar atau apresiasi akan menurunkan nilai ekspor di kawasan RCEP karena masyarakat akan cenderung lebih memilih impor dikarenakan harga barang yang lebih murah. 
Sedangkan tarif menunjukkan hasil yang negatif tidak siginifikan, artinya bahwa tarif memiliki pengaruh yang negatif terhadap ekspor karena semakin meningkatnya tarif maka akan menurunkan nilai ekspor dikawasan RCEP namun pada penelitian ini tidak signifikan berpengaruh, hal ini sejalan dengan semakin menurunnya hambatan tarif secara progresif maka upaya pemangkasan biaya perdagangan semakin terfokus pada ukuran hambatan non tarif yang berdampak buruk pada arus barang yang diperdagangkan secara internasional (Pellan dan Wong, 2015; Asian Development Bank dan United nation, 2013).

Hasil estimasi model kedua menunjukkan ekspor di kawasan RCEP berpengaruh negatif signifikan terhadap ketimpangan yaitu sebesar -0,010304, artinya bahwa peningkatan ekspor di kawasan RCEP akan menurunkan tingkat ketimpangan. Namun, sebuah pertanyaan muncul berdasarkan fakta dari berbagai penelitian yang menunjukkan adanya perdagangan apakah memberikan keuntungan untuk negara-negara maju, dan cenderung bersifat merugikan untuk kelompok negara-negara sedang berkembang atau sebaliknya.

Penelitian ini mengkoreksi hasil estimasi pengaruh keterbukaan perdagangan di kawasan RCEP secara agregat dengan memasukkan pengaruh dummy (negara-negara maju $=1$, negara-negara sedang berkembang $=0$ ) dan dummy yang diinteraksikan dengan ekspor pada estimasi berikutnya.

Hasil menunjukkan bahwa untuk kelompok negara-negara sedang berkembang nilai intersepnya lebih besar jika dibandingkan negara-negara maju. Rata-rata perbedaan ketimpangan antara negara-negara maju dan negaranegara sedang berkembang jika semua variabel independen lainnya sama dengan 0 adalah sebesar $-0,026005$. Seperti yang telah disebutkan sebelumnya hasil estimasi dari nilai slope ekspor untuk kelompok negaranegara sedang berkembang adalah negatif signifikan terhadap ketimpangan, namun untuk kelompok negaranegara maju menunjukkan positif signifikan. Hasil estimasi untuk slope dummy interaksi (ekspor $\mathrm{x}$ RCEP negara-negara maju) adalah sebagai berikut (nilai slope interaksi dummy slope ekspor yaitu sebesar 0,010292. Hal ini sejalan dengan temuan Cabote (2014) dan Cuong (2013) yang menjelaskan bahwa dengan adanya perdagangan maka dapat menurunkan ketimpangan dan kemiskinan di negaranegara sedang berkembang atau low income.

\section{KESIMPULAN DAN SARAN}

\section{Kesimpulan}

1. Biaya dan waktu yang digunakan untuk mengekspor di kawasan RCEP lebih rendah jika dibandingkan dengan negara-negara maju di kawasan RCEP, artinya kawasan RCEP merupakan kombinasi yang baik bagi kedua kelompok negara. Kemudian nilai ekspor kawasan RCEP yang cukup besar jika dibandingkan dengan dengan total nilai ekspor dunia, artinya bahwa kawasan RCEP memegang peranan ekspor yang cukup penting di dunia. Selanjutnya pergerakan nilai ekspor dan ketimpangan yang menunjukkan hubungan negatif di kawasan RCEP menyiratkan bahwa ekspor yang meningkat akan menurunkan ketimpangan. Secara analisis deskriptif dengan pergerakan data, dapat dilihat bahwa dengan adanya fasilitasi perdagangan di kawasan 
RCEP akan menurunkan biaya ekspor ke tingkat yang lebih rendah yang selanjutnya akan meningkatkan nilai ekspor dan menurunkan ketimpangan di kawasan RCEP.

2. Pengaruh semua variabel fasilitasi perdagangan dari negara pengekspor terhadap nilai ekspor adalah signifikan, artinya adanya perbaikan fasilitasi perdagangan dapat mempengaruhi nilai ekspor. Variabel lainnya GDP perkapita, jarak, bahasa, perbatasan, sejarah serta nilai tukar juga berpengaruh signifikan terhadap nilai ekspor kawasan RCEP. Sedangkan tarif menunjukkan hasil yang negatif namun tidak signifikan.

3. Ekspor kawasan RCEP menunjukkan hasil yang negatif signifikan terhadap ketimpangan. Hal ini menunjukkan bahwa peningkatan ekspor di kawasan RCEP akan menurunkan tingkat ketimpangan. Selanjutnya, hasil penelitian ini memisahkan negaranegara di Kawasan RCEP berdasarkan kelompok pendapatan menggunakan variabel dummy. Hasil menunjukkan hubungan negatif antara ekspor terhadap ketimpangan di Kawasan RCEP negara-negara sedang berkembang, sedangkan untuk negara-negara negara-negara maju menunjukkan keadaan sebaliknya. Hal ini menunjukkan bahwa dengan adanya integrasi perdagangan di kawasan RCEP ini memberikan efek yang positif bagi ketimpangan di negaranegara negara-negara sedang berkembang dengan ditunjukkan hasil estimasi yang negatif signifikan. Artinya dengan bergabung ke dalam kawasan RCEP negara negara-negara sedang berkembang dapat mengambil manfaat integrasi kawasan RCEP ini.

\section{Saran}

1. Integrasi ekonomi dan liberalisasi perdagangan memiliki dampak yang berbeda pada kelompok negara berdasarkan pendapatan, untuk itu diharapkan bagi otoritas agar memberikan perlakuan yang sesuai atau kesamaan perlakuan guna mendukung adanya pembentukan kawasan ekonomi seperti RCEP ini yang dapat memberikan manfaaat yang merata tidak hanya pada negara-negara maju tetapi juga negara-negara sedang berkembang.

2. Pemerintah negara-negara sedang berkembang khususnya Indonesia di kawasan RCEP diharapkan mempersiapkan fasilitasi perdagangan dan faktor lain seperti sumber daya manusia yang terampil untuk menghadapi negosiasi RCEP yang sedang berlangsung agar dapat memperbaiki serta memperluas akses pasar ekspornya tidak hanya pada ekspor yang berbasis pada SDA tetapi juga manufaktur. Selain itu diharapkan agar melakukan peninjauan ulang pada perjanjianperjanjian yang dinilai akan merugikan negara-negara sedang berkembang pada kawasan RCEP khususnya Indonesia mengingat perjanjian ini akan berdampak cukup besar bagi perdagangan dunia.

\section{DAFTAR PUSTAKA}

ADB and UN (Asian Development Bank and United Nation). 2013. Designing And Implenting Trade Facilitation In Asia And The Pacific Update 2013. Philippines: Publication of Asian Development Bank and united Nation Economic 
and Social Commission for Asia and the Pacific.

Cabote N. 2014. Trade Facilitation And Poverty In Developing Countries. Case Study in International Political Economy The University of Tokyo.

Cuong NV. 2013. Poverty, Inequality and Trade Facilitation in Low and Middle Income Countries. Munich Personal RePEc Archieve Paper No. 50312, posted 1. October 2013

Dollar D, Kraay A. 2000. Growth Is Good for the Poor, Development Research Group, Washington, D.C., World Bank.

Itakura K. 2014. Impact of Liberalization And Improved Connectivity and Facilitation In ASEAN. Journal of Asian Economics. $\mathrm{Xxx}$ : $\mathrm{xxx}-\mathrm{xxx}$. http://dx.doi.org/10.1016/j.asieco. 2014.09.002.

Marquez G. Pagés-Serra, C. 1998. Trade and Employment: Evidence from Latin America and the Caribbean. WP-366, InterAmerican Development Bank, Washington, D.C.

Matsumura A. 2016. Regional Trade Integration by Environmental Goods. Journal of Economic Integration. Vol.31 No.1, March 2016, 1-40.

Otsuki T, Honda K. Wilson, JS. 2012. Trade facilitation in South Asia. South Asian Journal of Global Business Research 2 (2): 172-190. Doi 10.1108/SAJGBR-12-20110052 .

Pellan MI, Wong MH. 2015. Trade Facilitation in ASEAN+6 Economies. ASEAN and Regional Free Trade Agreements. Economic Research Institute for ASEAN and East Asia (ERIA).
Perez-Portugal A, Wilson JS. 2012. Export Performance and Trade Facilitation Reform: Hard and Soft Infrastructure. World Development. Vol. 40, No. 7, pp. 1295-1307. doi:10.1016/j.worlddev.2011.12.0 0 .

Ravallion M. 2004. Pro-poor Growth: A Primer. World Bank Policy Research

Working Paper No. WPS3242, The World Bank.

Revenga A. 1997. Employment and Wage Effects of Trade Liberalization: The Case of Mexican Manufacturing. Journal of Labor Economics, Vol. 15(3), S20-S43.

Shepherd B, Wilson JS. 2009. Trade facilitation in ASEAN member countries: Measuring progress and assessing priorities. Journal of Asian Economics. 20 (2009) 367383.

doi:10.1016/j.asieco.2009.03.001.

Wilson JS. Mann, CL. Otsuki, T. 2005. Assessing the Potrential Benefit of Trade Facilitation: A Global Perspective. The World Economy World Development 40 (7):12951307.doi:10.1016/j.worlddev.2011 .12 